\begin{tabular}{|c|c|}
\hline Title & $\begin{array}{l}\text { Differential expression of progesterone receptor, FOX A 1, GA TA 3, and p53 between pre and postmenopausal women } \\
\text { with estrogen receptor-positive breast cancer }\end{array}$ \\
\hline Author(s) & $\begin{array}{l}\text { Hosoda, Mitsuchika; Y amamoto, Mitsugu; Nakano, Kiichiroh; Hatanaka, Kanako C.; T akakuwa, Emi; Hatanaka, } \\
\text { Y utaka; Matsuno, Y oshihiro; Y amashita, Hiroko }\end{array}$ \\
\hline Citation & $\begin{array}{l}\text { Breast Cancer Research and T reatment, 144(2), 249-261 } \\
\text { https://doi.org/10.1007/s10549-014-2867-0 }\end{array}$ \\
\hline Issue Date & $2014-04$ \\
\hline Doc URL & http:/hdl.handle.net/2115/58539 \\
\hline Rights & The final publication is available at link.springer.com \\
\hline Type & article (author version) \\
\hline File Information & Breast Cancer Res Treat_144(2)_249-261.pdf \\
\hline
\end{tabular}

Instructions for use 


\section{Differential expression of progesterone receptor, FOXA1, GATA3 and p53 between pre- and postmenopausal women with estrogen receptor-positive breast cancer}

Mitsuchika Hosoda ${ }^{1}$, Mitsugu Yamamoto ${ }^{1}$, Kiichiroh Nakano ${ }^{1}$, Kanako C. Hatanaka ${ }^{2}$, Emi

Takakuwa $^{2,3}$, Yutaka Hatanaka ${ }^{2,3}$, Yoshihiro Matsuno ${ }^{2,3}$, Hiroko Yamashita ${ }^{1, *}$

${ }^{1}$ Breast and Endocrine Surgery, Hokkaido University Hospital, Kita 14 Nishi 5, Kita-ku, Sapporo 060-8648, Japan

${ }^{2}$ Department of Surgical Pathology, Hokkaido University Hospital, Kita 14 Nishi 5, Kita-ku, Sapporo 060-8648, Japan

${ }^{3}$ Research Division of Companion Diagnostics, Hokkaido University Hospital, Kita 14 Nishi 5, Kita-ku, Sapporo 060-8648, Japan

*Correspondence author:

Hiroko Yamashita

Breast and Endocrine Surgery, Hokkaido University Hospital,

Kita 14, Nishi 5, Kita-ku, Sapporo 060-8648, Japan

Phone: +81-11-706-7381

Fax: +81-11-706-7384

E-mail: hirokoy@huhp.hokudai.ac.jp 


\section{Abstract}

Estrogen receptor (ER) is essential for estrogen-dependent growth, and its level of expression is considered a crucial determinant of response to endocrine therapy and prognosis in ER-positive breast cancer. On the other hand, the clinical role of progesterone receptor (PgR) in ER-positive breast cancer remains controversial, although testing of PgR by immunohistochemistry (IHC) has become routine. Recent studies indicated that plasma estradiol levels were related to expression levels of estrogen-responsive genes in ER-positive breast cancer tissues in both preand postmenopausal women. In this study, we analyzed expression levels of estrogen-responsive genes (PgR and TFF1), a progesterone-responsive gene (RANKL), ER-related genes (FOXA1 and GATA3), HER2, Ki67 and p53 in ER-positive, HER2-negative breast cancer tissues by IHC. Correlations between expression levels of these molecular markers and clinicopathological factors, including prognosis, were compared between pre- and postmenopausal women. Serum levels of estrone, estradiol, progesterone and testosterone were also measured. Expression levels of PgR, TFF1, RANKL and GATA3 were significantly higher in premenopausal women than in postmenopausal women. Serum estradiol levels were positively correlated with Ki67 labeling index (LI) in premenopausal women, but not in postmenopausal women. High expression of FOXA1 and GATA3 was significantly associated with improved disease-free survival in premenopausal women, but not in postmenopausal women, whereas high expression of PgR and low expression of p53 was significantly correlated with improved disease-free survival in postmenopausal women, but not in premenopausal women. Moreover, the best cutoff points of 
Ki67 LI for disease-free survival were $30 \%$ for premenopausal women and $14 \%$ for postmenopausal women. Expression levels of ER, TFF1 and RANKL were not associated with disease-free survival in either pre- or postmenopausal women. Our results suggest that the mechanisms of development and estrogen-dependent growth of ER-positive breast cancer might differ according to menopausal status.

\title{
Keywords
}

breast cancer, progesterone receptor, FOXA1, GATA3, Ki67, p53

\begin{abstract}
Abbreviations
ER, estrogen receptor; PgR, progesterone receptor; TFF1, trefoil factor 1; RANKL, receptor activator of NF-kappa B ligand; FOXA1, forkhead box A1; GATA3, GATA binding protein 3; HER2, human epidermal growth factor receptor type 2; Ki67 LI, Ki67 labeling index; IHC, immunohistochemistry; BMI, body mass index
\end{abstract}




\section{Introduction}

Estrogen receptor (ER) is essential for estrogen-dependent growth, and its level of expression is considered a crucial determinant of response to endocrine therapy and prognosis in ER-positive breast cancer [1-4]. On the other hand, the clinical role of progesterone receptor $(\mathrm{PgR})$ in ER-positive breast cancer remains controversial, although testing of $\mathrm{PgR}$ by immunohistochemistry (IHC) has become routine [5].

It was reported that quantitative analysis of ER and PgR expression provided highly significant information on risk of early relapse in postmenopausal patients in the Tamoxifen and Exemestane Adjuvant Multinational trial [4]. It has been demonstrated that ER-positive, PgR-negative tumors are a distinct subset of breast cancers characterized by aggressive behavior and tamoxifen resistance [6]. Cancello and colleagues analyzed 4,837 women with breast cancer defined as luminal B (ER-positive and/or PgR-positive, HER2-positive and/or Ki67 $\geq 14 \%$ by IHC classification [7]) and found that PgR loss identified luminal B breast cancer subgroups at higher risk of relapse and death regardless of HER2 status [8]. It was recently reported that semiquantitative IHC expression of PgR added prognostic value in luminal A breast cancer [9]. In contrast, the EBCTCG study showed the benefit of adjuvant tamoxifen in reducing risk of recurrence regardless of $\mathrm{PgR}$ status in ER-positive breast cancer [10].

We previously reported that expression levels of $\mathrm{PgR}$ in pretreatment biopsies were not predictive of the response to neoadjuvant exemestane therapy, and that expression levels of PgR were decreased in posttreatment tumors compared to the levels in pretreatment specimens 
regardless of the treatment response [11]. PgR is one of the estrogen-responsive genes, and it has been reported that plasma estradiol levels are related to expression levels of estrogen-responsive genes, such as $P G R$ and trefoil factor $1(T F F 1) / p S 2$, in ER-positive breast cancer in both preand postmenopausal women $[12,13]$. We previously showed that the incidence of ER-positive, PgR-negative breast cancer in women aged 50 years or younger and in those older than 50 years were $6 \%$ and $15 \%$, respectively, whereas for ER-positive, PgR-positive tumors, incidences were $81 \%$ and $64 \%$, respectively [14]. Moreover, most tumors had high PgR expression in women aged 50 or younger, while the distribution of PgR expression levels was evenly spread in tumors in women over 50 years of age. It is suggested that reduced circulating estrogens after menopause could be the cause of the increase of ER-positive/PgR-negative or ER-positive/low-PgR tumors in postmenopausal women [15]. On the other hand, PgR does not fully reflect estrogen dependence: many PgR-negative tumors respond to endocrine therapy, such as tamoxifen or aromatase inhibitors [11, 16-18].

We hypothesized that the clinical role of expression of estrogen-responsive genes may differ between pre- and postmenopausal women with ER-positive breast cancer. The present study was undertaken to assess expression of estrogen-responsive genes (PgR and TFF1), a progesterone-responsive gene (RANKL), ER-related genes (FOXA1 and GATA3), HER2, Ki67 and p53 in ER-positive, HER2-negative breast cancer samples by IHC. Correlations between expression levels of these molecular markers and clinicopathological factors, including prognosis, were compared between pre- and postmenopausal women. 


\section{Materials and methods}

\section{Patients and breast cancer tissues}

A total of 289 women treated for Stage I to III breast cancer between 2004 and 2010 at Hokkaido University Hospital were recruited to this study (Table 1). The study protocol was approved by the institutional review board and conformed to the guidelines of the 1996 Declaration of Helsinki. Written informed consent for the use of surgically resected tumor tissues was provided by all patients prior to treatments. The samples were chosen from a continuous series of ER-positive, HER2-negative breast cancer. All patients had undergone mastectomy or lumpectomy. Patients treated with neoadjuvant chemotherapy were excluded. Tumor samples were obtained during surgery. Patients received adequate endocrine or chemotherapy as adjuvant therapy, and patients who had positive results of axillary lymph node dissection received adjuvant chemotherapy, as well as adjuvant endocrine therapy. The median follow-up period was 66.2 months (range, 3 to 114 months).

\section{Immunohistochemical (IHC) analysis}

One $4-\mu \mathrm{m}$ section of each submitted paraffin block was stained first with hematoxylin-eosin to verify that an adequate number of carcinoma cells were present and that the fixation quality was adequate for IHC analysis. Serial sections $(4 \mu \mathrm{m})$ were then prepared from selected blocks and float-mounted on adhesive-coated glass slides for IHC. Details of antibodies and evaluation methods are described in Table 2, and representative images of staining for TFF1, RANKL, 
FOXA1 and GATA3 are shown in Figure 1. p53 was considered positive if there was $\geq 10 \%$ positive nuclear staining regardless of the intensity [19-21]. The Ki67 labeling index (LI) was assessed as the percentage of tumor cells showing definite nuclear staining among >1000 invasive tumor cells using NanoZoomer 2.0-HT (Hamamatsu photonics, Hamamatsu, Japan) for slide scanning and Tissue Studio (Definiens, Munich, Germany) for automated scoring [22]. HER2-positive tumors were excluded from this study.

\section{Measurements of serum samples}

Blood samples were taken at the time of surgery and centrifuged at $1300 \mathrm{~g}$ for 10 minutes, then the separated sera were stored in aliquots at $-20{ }^{\circ} \mathrm{C}$. Serum samples were obtained from 19 premenopausal patients and 49 postmenopausal patients. The concentration of serum estrone (E1) was measured by radioimmunoassay (dextran coated charcoal method) using anti-estrone-antiserum (ASKA Pharma Medical Co., Kawasaki, Japan) according to the manufacturer's instructions. The concentration of estradiol (E2) was measured using a commercially available direct radioimmunoassay; RIACOAT ESTRADIOL US (CIS bio international, Gif-sur-Yvette, France) for estradiol [14]. Serum progesterone and testosterone levels were measured by electrochemiluminescence immunoassay using Ecrusis progesterone II and Ecrusis Testosterone, respectively (Roche Diagnostics, Tokyo, Japan).

\section{Statistical analysis}


Mann-Whitney $U$ tests were used to compare expression of biological markers and serum hormone levels between pre- and postmenopausal women. Spearman's rank correlation test was used to study relationships between expression levels of biological markers and clinicopathological factors. Spearman's correlation coefficient $>+0.40$ or $<-0.40$ and $P<0.05$ in Spearman's rank correlation test were considered significant. Estimation of disease-free survival was performed using the Kaplan-Meier method, and differences between survival curves were assessed with the log-rank test. Cox's proportional hazards model was used for univariate and multivariate analyses of prognostic values. 


\section{Results}

Comparison of expression levels of biological markers between pre- and postmenopausal women

We first examined expression levels of biological factors, including ER, PgR, TFF1, RANKL, FOXA1, GATA3, HER2, Ki67 and p53 in pre- and postmenopausal breast cancer tissues (Table 3). Expression levels of PgR, TFF1, RANKL and GATA3 were significantly higher in premenopausal women than in postmenopausal women $(P<0.0001, P=0.0002, P=0.0005$ and $P<0.0001$, respectively). In contrast, expression levels of ER, FOXA1, HER2, Ki67 and p53 did not differ between pre- and postmenopausal women.

Expression levels of ER, PgR and Ki67 were then analyzed in detail in pre- and postmenopausal women. Most tumors in both pre- and postmenopausal women showed high ER expression (90\% or more positive cells) (Fig. 2a, b). In contrast, in premenopausal women, most tumors had high PgR expression, with $90 \%$ or more positive cells (Fig. 2a), whereas in postmenopausal women $30 \%$ of the tumors were PgR-negative and the distribution of frequencies of PgR positive cells was evenly spread (Fig. 2b). On the other hand, the distribution of frequencies of Ki67 LI was similar between pre- and postmenopausal women (Fig. 2c, d).

\section{Comparison of serum hormone levels between pre- and postmenopausal women}

Serum levels of E1, E2, progesterone and testosterone were measured in 19 premenopausal and 49 postmenopausal women (Table 4). E1, E2 and progesterone levels were significantly higher in 
premenopausal women than in postmenopausal women $(P=0.001, P=0.002$ and $P=0.039$, respectively). Serum testosterone levels did not differ between pre- and postmenopausal women.

\section{Correlations between expression levels of biological markers in pre- and postmenopausal}

\section{women}

Links between expression levels of biological markers were analyzed using Spearman's rank correlation test (Table 5). In premenopausal women, expression levels of ER were positively correlated with those of PgR, FOXA1 and GATA3, although those were not statistically significant (Spearman's correlation coefficient; $+0.364(P=0.0004),+0.255(P=0.019)$ and $+0.313(P=0.0035)$, respectively). On the other hand, expression levels of ER were positively correlated with those of PgR, FOXA1, GATA3 and HER2 in postmenopausal women (Spearman's correlation coefficient; $+0.272(P=0.0001),+0.338(P<0.0001),+0.305(P<$ $0.0001)$ and $+0.233(P=0.0009)$, respectively). $\mathrm{PgR}$ expression was positively correlated with FOXA1 and GATA3 expression in pre-menopausal women (Spearman's correlation coefficient; $+0.262(P=0.016)$ and $+0.224(P=0.039)$, respectively), whereas $\mathrm{PgR}$ expression was not correlated with expression of other biological markers except ER in postmenopausal women. TFF1 expression was positively correlated with RANKL expression in premenopausal women (Spearman's correlation coefficient; $+0.347(P=0.0011)$ ), whereas TFF1 expression was positively correlated with FOXA1 and Ki67 expression in postmenopausal women (Spearman's correlation coefficient; $+0.260(P=0.0002)$ and $+0.215(P=0.003)$, respectively $)$. Expression 
levels of FOXA1 and GATA3 were strongly and positively correlated in both pre- and postmenopausal women (Spearman's correlation coefficient; $+0.436(P<0.0001)$ and $+0.479(P$ $<0.0001$ ), respectively). FOXA1 expression was positively correlated with RANKL expression in postmenopausal women (Spearman's correlation coefficient; $+0.253(P=0.0003)$ ), but not in premenopausal women. Expression levels of Ki67 and p53 were positively correlated in both pre- and postmenopausal women (Spearman's correlation coefficient; $+0.322(P=0.0030)$ and $+0.390(P<0.0001)$, respectively)

\section{Correlations between expression levels of biological markers and clinicopathological}

\section{factors in pre- and postmenopausal women}

We next analyzed the correlation between expression levels of biological markers and clinicopathological factors, such as age, body mass index (BMI), tumor size, nodal status and tumor grade in pre- and postmenopausal women (Table 6). RANKL expression was negatively associated with tumor size in both pre- and postmenopausal women (Spearman's correlation coefficient; $-0.362(P=0.0007)$ and $-0.207(P=0.0035)$, respectively). GATA3 expression was negatively correlated with tumor size and lymph node status in premenopausal women (Spearman's correlation coefficient; $-0.239(P=0.028)$ and $-0.304(P=0.0050)$, respectively), but not in postmenopausal women. Ki67 LI was negatively correlated with age (Spearman's correlation coefficient; $-0.326(P=0.0027))$ and positively associated with tumor grade (Spearman's correlation coefficient; $+0.356(P=0.010))$ in premenopausal women. On the other 
hand, Ki67 LI was positively correlated with tumor size and grade in postmenopausal women (Spearman's correlation coefficient; $+0.295(P<0.0001)$ and $+0.262(P=0.0003)$, respectively). p53 expression was negatively correlated with age (Spearman's correlation coefficient; $-0.230(P$ $=0.032)$ ) in premenopausal women, whereas p53 expression was positively correlated with tumor grade in postmenopausal women (Spearman's correlation coefficient; $+0.270(P=$ 0.0001)). Expression of ER, PgR, TFF1, FOXA1 and HER2 was not associated with clinicopathological factors in either pre- or postmenopausal women.

\section{Correlations between serum hormone levels and biological and clinicopathological factors}

Serum hormone levels, such as E1, E2, progesterone and testosterone, were compared with expression levels of biological and clinicopathological factors in pre- and postmenopausal women. Serum E2 was positively correlated with tumor size and Ki67 LI (Spearman's correlation coefficient; +0.429 and +0.444 , respectively) and negatively correlated with age (Spearman's correlation coefficient; -0.515) in premenopausal women. Serum testosterone was negatively correlated with age (Spearman's correlation coefficient; -0.555) in premenopausal women. Serum E2 was negatively correlated with age (Spearman's correlation coefficient; -0.314) in postmenopausal women. Other serum hormone levels analyzed in this study were not correlated with biological or clinicopathological factors in either pre- or postmenopausal women.

\section{Biological factors related to survival differ between pre- and postmenopausal women}


To identify a clinically meaningful cutoff point for each biological factor, various levels of expression were tested using Kaplan-Meier analysis and verified by the log-rank test for disease-free survival. When the cutoff points for determining the division between negative, low and high expression of $\mathrm{PgR}$ were set as $1 \%$ and $50 \%$ in postmenopausal women, Kaplan-Meier analysis showed that high $\mathrm{PgR}$ expression was significantly correlated with increased disease-free survival compared with no PgR expression ( $P=0.031$; Fig. $3 b)$. The survival curve of low PgR expression (1\%-50\%) was almost identical to that of high PgR expression (>50\%). In contrast, PgR expression was not correlated with disease-free survival in premenopausal women (Fig. 3a). When the cutoff points for determining the division between low and high expression were set at 70\% for FOXA1, 80\% for GATA3 and 30\% for Ki67 in premenopausal women, high FOXA1 (Fig. 3c), high GATA3 (Fig. 3e) and low Ki67 (Fig. 3i) expression was strongly associated with increased disease-free survival $(P<0.0001, P=0.0059$ and $P=0.0004$, respectively). On the other hand, in postmenopausal women, when the cutoff point for determining the division between low and high Ki67 LI was set at 14\%, low Ki67 LI was strongly associated with increased disease-free survival $(P=0.0005$; Fig. 3 h). In contrast, expression of FOXA1 (Fig. 3d) and GATA3 (Fig. 3f) was not correlated with disease-free survival in postmenopausal women. When the cutoff point for determining the division between low and high expression of p53 was set at 10\%, low p53 expression was strongly associated with increased disease-free survival in postmenopausal women $(P<0.0001$; Fig. 31). Surprisingly, p53 expression levels were less than $10 \%$ in all the premenopausal women who relapsed (Fig. 
$3 \mathrm{k})$.

We then analyzed whether expression levels of biological markers were associated with altered prognosis of premenopausal patients with ER-positive, HER2-negative breast cancer (Table 7). Univariate analysis demonstrated significant association between improved disease-free survival and expression of high FOXA1 $(P=0.0006)$, high GATA3 $(P=0.029)$ and low $(<30 \%) \mathrm{Ki67}(P=0.0045)$, as well as small tumor size $(P=0.0003)$ and lymph node status $(P<0.0001)$. In multivariate analysis, a significant association was observed between disease-free survival and tumor size $(P=0.044)$ and Ki67 expression (cut off, 30\%) $(P=0.029)$. On the other hand, in postmenopausal women, univariate analysis showed a significant association between improved disease-free survival and expression of low $(<14 \%) \mathrm{Ki67}(P=$ 0.0014) and low p53 $(P=0.0001)$, as well as lymph node status $(P=0.047)$ and tumor grade $(P$ $=0.0085)$. In multivariate analysis, a significant correlation was observed between disease-free survival and p53 expression $(P=0.0061)$. Expression levels of ER, TFF1 and RANKL were not associated with disease-free survival in either pre- or postmenopausal women. 


\section{Discussion}

In this study, we analyzed expression of ER, PgR, TFF1, RANKL, FOXA1, GATA3, HER2,

Ki67 and p53 in ER-positive, HER2-negative breast cancer in pre- and postmenopausal women. Among our patients, expression levels of PgR, TFF1, RANKL and GATA3 were significantly higher in premenopausal women than in postmenopausal women. Expression of high FOXA1 and high GATA3 was significantly associated with improved disease-free survival in premenopausal women, but not in postmenopausal women, whereas expression of high PgR and low p53 was significantly correlated with improved disease-free survival in postmenopausal women, but not in premenopausal women. Moreover, the best cutoff points of Ki67 LI for disease-free survival were $30 \%$ for premenopausal women and $14 \%$ for postmenopausal women.

Most studies analyzing predictive or prognostic factors in ER-positive breast cancer have been performed in postmenopausal women, mainly using patients and samples in adjuvant aromatase inhibitor trials $[3,4,23]$. In premenopausal women, however, even the clinical role of PgR has been little analyzed so far. We previously analyzed genetic and environmental predictors, endogenous hormones and growth factors, and risk of ER-positive breast cancer, and demonstrated that risk factors differed between women of different menopausal status [24]. It has been reported that plasma estradiol levels are significantly associated with estrogen-responsive gene expression of ER-positive breast cancers in both pre- and postmenopausal women $[12,13]$. Because plasma E1, E2 and progesterone levels are much higher in premenopausal women compared with those in postmenopausal women as shown in this study, risk factors and 
biological characteristics of ER-positive breast cancer might differ according to menopausal status. We have shown that expression levels of PgR and TFF1 in breast cancer tissues were significantly higher in premenopausal women than in postmenopausal women. TFF1, originally known as $\mathrm{pS} 2$, was the gene which correlated most significantly with plasma estradiol concentration in postmenopausal ER-positive breast cancer tissues [13]. It was also reported that expression levels of TFF1, similar to PgR, in ER-positive breast tumors differed across the menstrual cycle in premenopausal women, although expression of proliferation genes, such as Ki67, did not differ during the cycle [12].

RANKL, involved in the control of bone remodeling [25], is one of the progesterone-responsive genes [26]. Previous studies identified RANKL as a pivotal paracrine mediator of progesterone function in mouse mammary gland development and mammary carcinogenesis [27]. It was recently reported that RANKL expression responded to progesterone and was required for progesterone-induced breast tissue proliferation [28]. In this study we found that expression levels of RANKL in breast cancer tissues were significantly higher in premenopausal women than in postmenopausal women, as serum progesterone levels were higher in premenopausal women compared with postmenopausal women. However, our results also indicate that RANKL expression is inversely correlated with tumor size in both pre- and postmenopausal women, suggesting that the progesterone-RANKL pathway may not be involved in estrogen-dependent growth in ER-positive breast cancer.

FOXA1, a forkhead family transcription factor, is reportedly expressed predominantly 
in luminal A breast cancer with favorable prognosis [29-32]. We recently demonstrated that FOXA1 expression is much higher in ER-high, Ki67-low tumors than in ER-low, Ki67-high tumors [33]. GATA3 is also a transcription factor which is critical for normal mammary development [34]. Recent whole genome analysis identified a GATA3 mutation which exists in $14 \%$ of luminal A breast cancer [35]. It was reported that ER $\alpha$, FOXA1 and GATA3 form a functional enhanceosome to drive the transcription of ER $\alpha$-regulated genes in breast cancer cells [36, 37]. High FOXA1 and GATA3 expression might therefore affect endocrine responsiveness and prognosis in ER-positive breast cancer [38]. However, menopausal status has not been considered in previous studies on FOXA1 and GATA3 in ER-positive breast cancer. We demonstrate in this study that expression of GATA3 is significantly higher in premenopausal women than in postmenopausal women. Moreover, expression of high FOXA1 and high GATA3 is significantly associated with improved disease-free survival in premenopausal women, but not in postmenopausal women, although FOXA1 and GATA3 expression is strongly correlated in both pre- and postmenopausal women. The mechanism of estrogen-dependent growth and the clinical role of FOXA1 and GATA3 in ER-positive breast cancer might differ with differing menopausal status.

We also identified that the best cutoff points of the Ki67 LI for disease-free survival were $30 \%$ for premenopausal women and $14 \%$ for postmenopausal women. Moreover, serum estradiol levels were positively associated with Ki67 LI in premenopausal women, but not in postmenopausal women. Furthermore, our results indicate that p53 accumulation is significantly 
correlated with decreased disease-free survival in postmenopausal women, but not in premenopausal women. Surprisingly, p53 expression levels were less than $10 \%$ in all premenopausal women who relapsed. Because the clinical significance of Ki67 LI and p53 alteration in premenopausal ER-positive breast cancer alone has not been reported, further studies will be necessary to confirm this point.

Finally, our data demonstrate that expression levels of ER correlate positively with HER2 expression score evaluated by IHC in postmenopausal women, but not in premenopausal women. Moreover, HER2 expression is not correlated with expression of other biological factors analyzed in this study in either pre- or postmenopausal women. It was recently reported that ER and HER2 expression, of both mRNA and protein, is positively correlated in HER2-negative tumors, validated by a TransATAC study for postmenopausal women [39].

In conclusion, the present study indicates that the clinical role of expression of estrogen-responsive genes (PgR and TFF1), a progesterone-responsive gene (RANKL), ER-related genes (FOXA1 and GATA3), HER2, Ki67 and p53 in ER-positive, HER2-negative breast cancer differs between pre- and postmenopausal women. Our results suggest that the mechanisms of development and estrogen-dependent growth of ER-positive breast cancer might differ according to menopausal status. 


\section{Acknowledgements}

The authors thank Mr. Jun Moriya and Mrs. Mikiko Sato for their technical assistance.

Disclosures: None. 


\section{References}

1. Harvey JM, Clark GM, Osborne CK, Allred DC (1999) Estrogen receptor status by immunohistochemistry is superior to the ligand-binding assay for predicting response to adjuvant endocrine therapy in breast cancer. J Clin Oncol 17:1474-81

2. Yamashita H, Yando Y, Nishio M, Zhang Z, Hamaguchi M, Mita K, Kobayashi S, Fujii Y, Iwase H (2006) Immunohistochemical evaluation of hormone receptor status for predicting response to endocrine therapy in metastatic breast cancer. Breast Cancer 13:74-83

3. Dowsett M, Allred C, Knox J, Quinn E, Salter J, Wale C, Cuzick J, Houghton J, Williams $\mathrm{N}$, Mallon E, et al (2008) Relationship between quantitative estrogen and progesterone receptor expression and human epidermal growth factor receptor 2 (HER-2) status with recurrence in the Arimidex, Tamoxifen, Alone or in Combination trial. J Clin Oncol 26:1059-65

4. Bartlett JM, Brookes CL, Robson T, van de Velde CJ, Billingham LJ, Campbell FM, Grant M, Hasenburg A, Hille ET, Kay C, et al (2011) Estrogen receptor and progesterone receptor as predictive biomarkers of response to endocrine therapy: a prospectively powered pathology study in the Tamoxifen and Exemestane Adjuvant Multinational trial. J Clin Oncol 29:1531-8

5. Hammond ME, Hayes DF, Dowsett M, Allred DC, Hagerty KL, Badve S, Fitzgibbons PL, Francis G, Goldstein NS, Hayes M, et al (2010) American Society of Clinical Oncology/College Of American Pathologists guideline recommendations for immunohistochemical testing of estrogen and progesterone receptors in breast cancer. $\mathrm{J}$ Clin Oncol 28:2784-95

6. Thakkar JP, Mehta DG (2011) A review of an unfavorable subset of breast cancer: estrogen receptor positive progesterone receptor negative. Oncologist 16:276-85

7. Goldhirsch A, Wood WC, Coates AS, Gelber RD, Thurlimann B, Senn HJ (2011) Strategies for subtypes--dealing with the diversity of breast cancer: highlights of the St. Gallen International Expert Consensus on the Primary Therapy of Early Breast Cancer 2011. Ann Oncol 22:1736-47

8. Cancello G, Maisonneuve P, Rotmensz N, Viale G, Mastropasqua MG, Pruneri G, Montagna E, Iorfida M, Mazza M, Balduzzi A, et al (2013) Progesterone receptor loss identifies Luminal B breast cancer subgroups at higher risk of relapse. Ann Oncol 24:661-8

9. Prat A, Cheang MC, Martin M, Parker JS, Carrasco E, Caballero R, Tyldesley S, Gelmon K, Bernard PS, Nielsen TO, et al (2013) Prognostic significance of progesterone receptor-positive tumor cells within immunohistochemically defined luminal A breast cancer. J Clin Oncol 31:203-9

10. Davies C, Godwin J, Gray R, Clarke M, Cutter D, Darby S, McGale P, Pan HC, Taylor C, Wang YC, et al (2011) Relevance of breast cancer hormone receptors and other factors to 
the efficacy of adjuvant tamoxifen: patient-level meta-analysis of randomised trials. Lancet 378:771-84

11. Yamashita H, Takahashi S, Ito Y, Yamashita T, Ando Y, Toyama T, Sugiura H, Yoshimoto N, Kobayashi S, Fujii Y, et al (2009) Predictors of response to exemestane as primary endocrine therapy in estrogen receptor-positive breast cancer. Cancer Sci 100:2028-33

12. Haynes BP, Viale G, Galimberti V, Rotmensz N, Gibelli B, A'Hern R, Smith IE, Dowsett M (2013) Expression of key oestrogen-regulated genes differs substantially across the menstrual cycle in oestrogen receptor-positive primary breast cancer. Breast Cancer Res Treat 138:157-65

13. Dunbier AK, Anderson H, Ghazoui Z, Folkerd EJ, A'Hern R, Crowder RJ, Hoog J, Smith IE, Osin P, Nerurkar A, et al (2010) Relationship between plasma estradiol levels and estrogen-responsive gene expression in estrogen receptor-positive breast cancer in postmenopausal women. J Clin Oncol 28:1161-7

14. Yamashita H, Iwase H, Toyama T, Takahashi S, Sugiura H, Yoshimoto N, Endo Y, Fujii Y, Kobayashi S (2011) Estrogen receptor-positive breast cancer in Japanese women: trends in incidence, characteristics, and prognosis. Ann Oncol 22:1318-25

15. Yamamoto Y, Yamamoto-Ibusuki M, Iwase H (2013) Menopausal status should be taken into consideration for patients with luminal a breast cancer in terms of the effect of differential biology on prognosis. J Clin Oncol 31:2516

16. Anderson H, Bulun S, Smith I, Dowsett M (2007) Predictors of response to aromatase inhibitors. J Steroid Biochem Mol Biol 106:49-54

17. Elledge RM, Green S, Pugh R, Allred DC, Clark GM, Hill J, Ravdin P, Martino S, Osborne CK (2000) Estrogen receptor (ER) and progesterone receptor (PgR), by ligand-binding assay compared with $\mathrm{ER}, \mathrm{PgR}$ and $\mathrm{pS} 2$, by immuno-histochemistry in predicting response to tamoxifen in metastatic breast cancer: a Southwest Oncology Group Study. Int J Cancer 89:111-7

18. Ellis MJ, Coop A, Singh B, Mauriac L, Llombert-Cussac A, Janicke F, Miller WR, Evans DB, Dugan M, Brady C, et al (2001) Letrozole is more effective neoadjuvant endocrine therapy than tamoxifen for ErbB-1- and/or ErbB-2-positive, estrogen receptor-positive primary breast cancer: evidence from a phase III randomized trial. J Clin Oncol 19:3808-16

19. Yamashita H, Toyama T, Nishio M, Ando Y, Hamaguchi M, Zhang Z, Kobayashi S, Fujii Y, Iwase H (2006) p53 protein accumulation predicts resistance to endocrine therapy and decreased post-relapse survival in metastatic breast cancer. Breast Cancer Res 8:R48

20. Millar EK, Graham PH, McNeil CM, Browne L, O'Toole SA, Boulghourjian A, Kearsley JH, Papadatos G, Delaney G, Fox C, et al (2011) Prediction of outcome of early ER+ breast cancer is improved using a biomarker panel, which includes Ki-67 and p53. Br J Cancer 105:272-80

21. Kobayashi T, Iwaya K, Moriya T, Yamasaki T, Tsuda H, Yamamoto J, Matsubara O (2013) A simple immunohistochemical panel comprising 2 conventional markers, Ki67 
and $\mathrm{p} 53$, is a powerful tool for predicting patient outcome in luminal-type breast cancer. BMC Clin Pathol 13:5

22. Yoshioka T, Hosoda M, Yamamoto M, Taguchi K, Hatanaka KC, Takakuwa E, Hatanaka Y, Matsuno Y, Yamashita H (2013) Prognostic significance of pathologic complete response and Ki67 expression after neoadjuvant chemotherapy in breast cancer. Breast Cancer

23. Viale G, Regan MM, Maiorano E, Mastropasqua MG, Dell'Orto P, Rasmussen BB, Raffoul J, Neven P, Orosz Z, Braye S, et al (2007) Prognostic and predictive value of centrally reviewed expression of estrogen and progesterone receptors in a randomized trial comparing letrozole and tamoxifen adjuvant therapy for postmenopausal early breast cancer: BIG 1-98. J Clin Oncol 25:3846-52

24. Yoshimoto N, Nishiyama T, Toyama T, Takahashi S, Shiraki N, Sugiura H, Endo Y, Iwasa M, Fujii Y, Yamashita H (2011) Genetic and environmental predictors, endogenous hormones and growth factors, and risk of estrogen receptor-positive breast cancer in Japanese women. Cancer Sci 102:2065-72

25. Dougall WC (2012) Molecular pathways: osteoclast-dependent and osteoclast-independent roles of the RANKL/RANK/OPG pathway in tumorigenesis and metastasis. Clinical cancer research : an official journal of the American Association for Cancer Research 18:326-35

26. Lydon JP (2010) Stem cells: Cues from steroid hormones. Nature 465:695-6

27. Brisken C (2013) Progesterone signalling in breast cancer: a neglected hormone coming into the limelight. Nat Rev Cancer 13:385-96

28. Tanos T, Sflomos G, Echeverria PC, Ayyanan A, Gutierrez M, Delaloye JF, Raffoul W, Fiche M, Dougall W, Schneider P, et al (2013) Progesterone/RANKL is a major regulatory axis in the human breast. Sci Transl Med 5:182ra55

29. Mehta RJ, Jain RK, Leung S, Choo J, Nielsen T, Huntsman D, Nakshatri H, Badve S (2012) FOXA1 is an independent prognostic marker for ER-positive breast cancer. Breast Cancer Res Treat 131:881-90

30. Badve S, Turbin D, Thorat MA, Morimiya A, Nielsen TO, Perou CM, Dunn S, Huntsman DG, Nakshatri H (2007) FOXA1 expression in breast cancer--correlation with luminal subtype A and survival. Clinical cancer research : an official journal of the American Association for Cancer Research 13:4415-21

31. Habashy HO, Powe DG, Rakha EA, Ball G, Paish C, Gee J, Nicholson RI, Ellis IO (2008) Forkhead-box A1 (FOXA1) expression in breast cancer and its prognostic significance. European journal of cancer 44:1541-51

32. Hisamatsu Y, Tokunaga E, Yamashita N, Akiyoshi S, Okada S, Nakashima Y, Aishima S, Morita M, Kakeji Y, Maehara Y (2012) Impact of FOXA1 expression on the prognosis of patients with hormone receptor-positive breast cancer. Annals of surgical oncology 19:1145-52

33. Endo Y, Toyama T, Takahashi S, Yoshimoto N, Iwasa M, Asano T, Fujii Y, Yamashita H 
(2013) miR-1290 and its potential targets are associated with characteristics of estrogen receptor alpha-positive breast cancer. Endocr Relat Cancer 20:91-102

34. Kouros-Mehr H, Slorach EM, Sternlicht MD, Werb Z (2006) GATA-3 maintains the differentiation of the luminal cell fate in the mammary gland. Cell 127:1041-55

35. (2012) Comprehensive molecular portraits of human breast tumours. Nature 490:61-70

36. Kong SL, Li G, Loh SL, Sung WK, Liu ET (2011) Cellular reprogramming by the conjoint action of ERalpha, FOXA1, and GATA3 to a ligand-inducible growth state. Mol Syst Biol 7:526

37. Lam EW, Brosens JJ, Gomes AR, Koo CY (2013) Forkhead box proteins: tuning forks for transcriptional harmony. Nat Rev Cancer 13:482-95

38. Jacquemier J, Charafe-Jauffret E, Monville F, Esterni B, Extra JM, Houvenaeghel G, Xerri L, Bertucci F, Birnbaum D (2009) Association of GATA3, P53, Ki67 status and vascular peritumoral invasion are strongly prognostic in luminal breast cancer. Breast Cancer Res 11:R23

39. Pinhel I, Hills M, Drury S, Salter J, Sumo G, A'Hern R, Bliss JM, Sestak I, Cuzick J, Barrett-Lee P, et al (2012) ER and HER2 expression are positively correlated in HER2 non-overexpressing breast cancer. Breast Cancer Res 14:R46 


\section{Figure legends}

Fig. 1 Immunohistochemical examination of TFF1 (a), RANKL (b), FOXA1 (c) and GATA3 (d) in invasive breast carcinoma. Representative results of positive staining are shown. Cytoplasmic staining of TFF1 (a) and RANKL (b) and nuclear staining of FOXA1 (c) and GATA3 (d) are seen in breast cancer cells.

Fig. 2 Expression levels of estrogen receptor (ER) and progesterone receptor (PgR) assessed by percentage of positive cells in ER-positive, HER2-negative breast cancer in premenopausal (a) and postmenopausal (b) women. Ki67 labeling index (LI) in ER-positive, HER2-negative breast cancer in premenopausal (c) and postmenopausal (d) women.

Fig. 3 Disease-free survival according to expression of PgR (a, b), FOXA1 (c, d), GATA3 (e, f),

Ki67 (g, h cut off, 14\%; i, j cut off, 30\%) and p53 (k, l) in ER-positive, HER2-negative breast cancer in premenopausal (a, $\mathbf{c}, \mathbf{e}, \mathbf{g}, \mathbf{i}, \mathbf{k})$ and postmenopausal $(\mathbf{b}, \mathbf{d}, \mathbf{f}, \mathbf{h}, \mathbf{j}, \mathbf{l})$ women. 
Table 1: Clinicopathological characteristics of patients and tumors

\begin{tabular}{|c|c|c|c|}
\hline & & Premenopausal & Postmenopausal \\
\hline \multicolumn{2}{|l|}{ No. of patients } & 89 & 200 \\
\hline age (years) & mean $\pm \mathrm{SD}$ (range) & $44.7 \pm 5.1(27-56)$ & $63.4 \pm 8.5(42-92)$ \\
\hline Body mass index & mean $\pm \mathrm{SD}$ (range) & $22.1 \pm 3.8(15.2-34.9)$ & $24.4 \pm 4.3(13.6-40.9)$ \\
\hline \multirow[t]{3}{*}{ Tumor size (cm) } & $\leq 2.0$ & $72(81 \%)$ & $142(71 \%)$ \\
\hline & $2.1-5.0$ & $15(17 \%)$ & $50(25 \%)$ \\
\hline & $>5.0$ & $3(3 \%)$ & $8(4 \%)$ \\
\hline \multirow{3}{*}{$\begin{array}{l}\text { No. of positive } \\
\text { lymph nodes }\end{array}$} & 0 & $63(71 \%)$ & $159(80 \%)$ \\
\hline & $1-3$ & $21(24 \%)$ & $31(16 \%)$ \\
\hline & $\geq 4$ & $5(6 \%)$ & $10(5 \%)$ \\
\hline \multirow[t]{3}{*}{ Tumor grade } & 1 & $32(36 \%)$ & $50(25 \%)$ \\
\hline & 2 & $49(55 \%)$ & $134(67 \%)$ \\
\hline & 3 & $8(9 \%)$ & $16(8 \%)$ \\
\hline \multirow[t]{2}{*}{ Histology } & Invasive ductal carcinoma & $73(82 \%)$ & $177(87 \%)$ \\
\hline & Others & $16(18 \%)$ & $23(13 \%)$ \\
\hline \multirow[t]{2}{*}{ Surgery type } & Mastectomy & $35(39 \%)$ & $102(51 \%)$ \\
\hline & Lumpectomy & $54(61 \%)$ & $98(49 \%)$ \\
\hline \multicolumn{4}{|c|}{ Postoperative adjuvant therapy } \\
\hline \multicolumn{2}{|l|}{ None } & $8(9 \%)$ & $9(4 \%)$ \\
\hline \multicolumn{2}{|c|}{ Any endocrine therapy } & $81(91 \%)$ & $191(96 \%)$ \\
\hline & Tamoxifen & 30 & 14 \\
\hline & Tamoxifen + LHRH agonist & 39 & 0 \\
\hline & LHRH agonist & 6 & 0 \\
\hline & Aromatase inhibitors & 6 & 187 \\
\hline \multicolumn{2}{|c|}{ Combined endocrine therapy and chemotherapy } & $23(26 \%)$ & $33(17 \%)$ \\
\hline Follow-up (months) & mean $\pm \mathrm{SD}($ range $)$ & $63 \pm 29(7-112)$ & $68 \pm 26(3-114)$ \\
\hline
\end{tabular}

LHRH agonist, luteinizing hormone-releasing hormone agonist for a minimum of 2 years 
Table 2: List of antibodies used for immunohistochemical analysis

\begin{tabular}{|c|c|c|c|c|}
\hline & Antibody & Species (dilution) & $2^{\text {nd }}$ antibody & Evaluation \\
\hline ER & $\begin{array}{l}\text { Ventana Medical Systems }{ }^{\mathrm{a}} \text {, } \\
\text { SP1 }\end{array}$ & $\begin{array}{l}\text { rabbit monoclonal } \\
\text { (prediluted) }\end{array}$ & $\begin{array}{l}\text { Ventana iVIEW } \\
\text { DAB Detection Kit }\end{array}$ & $\begin{array}{l}\text { percentage of cells showing positive } \\
\text { nuclear staining }\end{array}$ \\
\hline PgR & $\begin{array}{l}\text { Ventana Medical Systems, } \\
\text { 1E2 }\end{array}$ & $\begin{array}{l}\text { rabbit monoclonal } \\
\text { (prediluted) }\end{array}$ & $\begin{array}{l}\text { Ventana iVIEW } \\
\text { DAB Detection Kit }\end{array}$ & $\begin{array}{l}\text { percentage of cells showing positive } \\
\text { nuclear staining }\end{array}$ \\
\hline TFF1 & Abcam $^{\text {b }, ~ S P M 313 ~}$ & $\begin{array}{l}\text { mouse monoclonal } \\
\text { (prediluted) }\end{array}$ & $\begin{array}{l}\text { Ventana iVIEW } \\
\text { DAB Detection Kit }\end{array}$ & $\begin{array}{l}\text { average cytoplasmic staining } \\
\text { intensity of positive cells }(0,1,2,3)\end{array}$ \\
\hline RANKL & $\begin{array}{l}\text { Santa Cruz Biotechnology }{ }^{c} \text {, } \\
\text { FL-317 }\end{array}$ & $\begin{array}{l}\text { rabbit polyclonal } \\
(1: 100)\end{array}$ & $\begin{array}{l}\text { DakoEnVison } \\
\text { FLEX system }\end{array}$ & $\begin{array}{l}\text { average cytoplasmic staining } \\
\text { intensity of positive cells }(0,1,2,3)\end{array}$ \\
\hline FOXA1 & $\begin{array}{l}\text { Santa Cruz Biotechnology, } \\
\text { Q-6 }\end{array}$ & $\begin{array}{l}\text { mouse monoclonal } \\
(1: 400)\end{array}$ & $\begin{array}{l}\text { Dako EnVison } \\
\text { FLEX system }\end{array}$ & $\begin{array}{l}\text { percentage of cells showing positive } \\
\text { nuclear staining }\end{array}$ \\
\hline GATA3 & Biocare Medical $^{\mathrm{d}}$, L50-823 & $\begin{array}{l}\text { mouse monoclonal } \\
(1: 400)\end{array}$ & $\begin{array}{l}\text { Dako EnVison } \\
\text { FLEX system }\end{array}$ & $\begin{array}{l}\text { percentage of cells showing positive } \\
\text { nuclear staining }\end{array}$ \\
\hline HER2 & $\begin{array}{l}\text { Ventana Medical Systems, } \\
\text { 4B5 }\end{array}$ & $\begin{array}{l}\text { rabbit monoclonal } \\
\text { (prediluted) }\end{array}$ & $\begin{array}{l}\text { Ventana iVIEW } \\
\text { DAB Detection Kit }\end{array}$ & $0,1+, 2+, 3+$ \\
\hline Ki67 & $\mathrm{DAKO}^{\mathrm{e}}, \mathrm{MIB}-1$ & $\begin{array}{l}\text { mouse monoclonal } \\
(1: 200)\end{array}$ & $\begin{array}{l}\text { Dako EnVison } \\
\text { FLEX system }\end{array}$ & labeling index \\
\hline p53 & DAKO, DO-7 & $\begin{array}{l}\text { mouse monoclonal } \\
(1: 200)\end{array}$ & $\begin{array}{l}\text { Dako EnVison } \\
\text { FLEX system }\end{array}$ & $\begin{array}{l}\text { percentage of cells showing positive } \\
\text { nuclear staining }\end{array}$ \\
\hline
\end{tabular}

\footnotetext{
${ }^{\mathrm{a}}$ Ventana Medical Systems, Tucson, USA

${ }^{\mathrm{b}}$ Abcam, Cambridge, UK

${ }^{\mathrm{c}}$ Santa Cruz Biotechnology, Dallas, USA

${ }^{\mathrm{d}}$ Biocare Medical, Concord, USA

${ }^{\text {e }}$ DAKO, Glostrup, Denmark
} 
Table 3. Comparison of expression levels of biological markers between pre- and postmenopausal women

\begin{tabular}{lccc}
\hline & $\begin{array}{c}\text { Premenopausal } \\
(\text { mean } \pm \text { SD })\end{array}$ & $\begin{array}{c}\text { Postmenopausal } \\
(\text { mean } \pm \text { SD })\end{array}$ & $P$ \\
\hline ER & $79.8 \pm 23.0 \%$ & $83.0 \pm 20.9 \%$ & 0.17 \\
PgR & $64.2 \pm 34.8 \%$ & $31.1 \pm 32.5 \%$ & $<0.0001^{*}$ \\
TFF1 & $1.97 \pm 0.72$ & $1.63 \pm 0.70$ & $0.0002^{*}$ \\
RANKL & $0.85 \pm 0.83$ & $0.48 \pm 0.68$ & $0.0005^{*}$ \\
FOXA1 & $91.8 \pm 16.5 \%$ & $88.5 \pm 22.5 \%$ & 0.17 \\
GATA3 & $81.2 \pm 26.5 \%$ & $63.8 \pm 37.0 \%$ & $<0.0001^{*}$ \\
HER2 & $0.78 \pm 0.75$ & $0.63 \pm 0.75$ & 0.11 \\
Ki67 & $13.9 \pm 12.6 \%$ & $12.2 \pm 9.6 \%$ & 0.27 \\
p53 & $6.84 \pm 15.7 \%$ & $5.23 \pm 15.6 \%$ & 0.43 \\
\hline
\end{tabular}

$* P<0.05$ is considered significant. 
Table 4. Comparison of serum hormone levels between pre- and postmenopausal women

\begin{tabular}{lccc}
\hline & $\begin{array}{c}\text { Premenopausal } \\
(\text { mean } \pm \text { SD })\end{array}$ & $\begin{array}{c}\text { Postmenopausal } \\
(\text { mean } \pm \text { SD })\end{array}$ & $P$ \\
\hline Estrone $(\mathrm{E} 1)(\mathrm{pg} / \mathrm{ml})$ & $197.3 \pm 115.8$ & $103.7 \pm 33.0$ & $0.001^{*}$ \\
Estradiol $(\mathrm{E} 2)(\mathrm{pg} / \mathrm{ml})$ & $158.5 \pm 207.3$ & $3.67 \pm 2.29$ & $0.002^{*}$ \\
Progesterone $(\mathrm{ng} / \mathrm{ml})$ & $2.86 \pm 6.19$ & $0.203 \pm 0.121$ & $0.039^{*}$ \\
Testosterone $(\mathrm{ng} / \mathrm{ml})$ & $0.273 \pm 0.131$ & $0.245 \pm 0.135$ & 0.227 \\
\hline
\end{tabular}

$* P<0.05$ is considered significant. 
Table 5. Correlations between expression levels of biological markers in pre- and postmenopausal women

\begin{tabular}{|c|c|c|c|c|c|c|c|c|}
\hline \multicolumn{9}{|c|}{ Premenopausal women } \\
\hline & ER & $\mathrm{PgR}$ & TFF1 & RANKL & FOXA1 & GATA3 & HER2 & Ki67 \\
\hline \multirow{2}{*}{$\mathrm{PgR}$} & $+0.364^{\mathrm{a}}$ & & & & & & & \\
\hline & $0.0004 * \mathrm{~b}$ & & & & & & & \\
\hline \multirow{2}{*}{ TFF1 } & +0.018 & -0.016 & & & & & & \\
\hline & 0.87 & 0.88 & & & & & & \\
\hline \multirow{2}{*}{ RANKL } & +0.103 & +0.009 & +0.347 & & & & & \\
\hline & 0.35 & 0.93 & $0.0011^{*}$ & & & & & \\
\hline \multirow{2}{*}{ FOXA1 } & +0.255 & +0.262 & +0.067 & -0.006 & & & & \\
\hline & $0.019^{*}$ & $0.016^{*}$ & 0.54 & 0.96 & & & & \\
\hline \multirow{2}{*}{ GATA3 } & +0.313 & +0.224 & -0.051 & -0.022 & $+0.436^{*}$ & & & \\
\hline & $0.0035^{*}$ & $0.039 *$ & 0.64 & 0.84 & $<0.0001^{*}$ & & & \\
\hline \multirow{2}{*}{ HER2 } & +0.094 & -0.064 & -0.175 & -0.077 & +0.190 & +0.114 & & \\
\hline & 0.39 & 0.56 & 0.11 & 0.49 & 0.085 & 0.30 & & \\
\hline \multirow{2}{*}{ Ki67 } & -0.004 & +0.023 & +0.097 & -0.101 & -0.020 & -0.129 & +0.100 & \\
\hline & 0.968 & 0.84 & 0.38 & 0.36 & 0.86 & 0.25 & 0.37 & \\
\hline \multirow{2}{*}{ p53 } & -0.098 & -0.080 & +0.065 & -0.042 & -0.014 & -0.094 & -0.001 & +0.322 \\
\hline & 0.37 & 0.46 & 0.55 & 0.70 & 0.90 & 0.39 & 0.99 & $0.0030 *$ \\
\hline
\end{tabular}

Postmenopausal women

\begin{tabular}{|c|c|c|c|c|c|c|c|c|}
\hline & ER & PgR & TFF1 & RANKL & FOXA1 & GATA3 & HER2 & Ki67 \\
\hline \multirow{2}{*}{ PgR } & $+0.272^{a}$ & & & & & & & \\
\hline & $0.0001 *^{\mathrm{b}}$ & & & & & & & \\
\hline \multirow{2}{*}{ TFF1 } & +0.0003 & -0.037 & & & & & & \\
\hline & 0.99 & 0.60 & & & & & & \\
\hline \multirow{2}{*}{ RANKL } & +0.102 & -0.019 & +0.061 & & & & & \\
\hline & 0.16 & 0.79 & 0.40 & & & & & \\
\hline \multirow{2}{*}{ FOXA1 } & +0.338 & +0.118 & +0.260 & +0.253 & & & & \\
\hline & $<0.0001 *$ & 0.098 & $0.0002^{*}$ & $0.0003^{*}$ & & & & \\
\hline \multirow{2}{*}{ GATA3 } & +0.305 & +0.093 & +0.132 & +0.125 & $+0.479 *$ & & & \\
\hline & $<0.0001 *$ & 0.196 & 0.065 & 0.080 & $<0.0001^{*}$ & & & \\
\hline \multirow{2}{*}{ HER2 } & +0.233 & +0.034 & -0.087 & -0.0068 & +0.137 & +0.138 & & \\
\hline & $0.0009 *$ & 0.635 & 0.22 & 0.92 & 0.055 & 0.053 & & \\
\hline \multirow{2}{*}{ Ki67 } & +0.073 & -0.014 & +0.215 & +0.095 & +0.170 & +0.128 & +0.136 & \\
\hline & 0.315 & 0.853 & $0.003 *$ & 0.20 & 0.019 & 0.079 & 0.062 & \\
\hline \multirow{2}{*}{ p53 } & -0.037 & -0.093 & +0.107 & +0.022 & +0.002 & -0.096 & +0.147 & +0.390 \\
\hline & 0.61 & 0.19 & 0.13 & 0.76 & 0.98 & 0.18 & 0.038 & $<0.0001 *$ \\
\hline
\end{tabular}

${ }^{\text {a }}$ Spearman's correlation coefficient

${ }^{\mathrm{b}} P$, Spearman's rank correlation test

*Spearman's correlation coefficient $>+0.40$ or $<-0.40$ and $P<0.05$ is considered significant. 
Table 6. Correlations between expression levels of biological markers and clinicopathological factors in preand postmenopausal women

\begin{tabular}{|c|c|c|c|c|c|}
\hline \multicolumn{6}{|c|}{ Premenopausal women } \\
\hline & age & BMI & Tumor size & Lymph node status & Tumor grade \\
\hline \multirow{2}{*}{ ER } & $-0.030^{\mathrm{a}}$ & -0.073 & -0.069 & -0.173 & -0.160 \\
\hline & $0.78^{\mathrm{b}}$ & 0.50 & 0.52 & 0.11 & 0.13 \\
\hline \multirow{2}{*}{ PgR } & -0.090 & -0.165 & -0.087 & -0.151 & -0.079 \\
\hline & 0.40 & 0.12 & 0.42 & 0.16 & 0.46 \\
\hline \multirow{2}{*}{ TFF1 } & +0.166 & +0.154 & -0.146 & -0.085 & +0.138 \\
\hline & 0.13 & 0.15 & 0.18 & 0.44 & 0.20 \\
\hline \multirow{2}{*}{ RANKL } & +0.121 & +0.020 & -0.362 & -0.208 & +0.011 \\
\hline & 0.27 & 0.86 & $0.0007^{*}$ & 0.058 & 0.92 \\
\hline \multirow{2}{*}{ FOXA1 } & +0.048 & -0.190 & -0.047 & -0.074 & -0.191 \\
\hline & 0.66 & 0.082 & 0.67 & 0.50 & 0.08 \\
\hline \multirow{2}{*}{ GATA3 } & -0.013 & -0.091 & -0.239 & -0.304 & -0.210 \\
\hline & 0.91 & 0.41 & $0.028 *$ & $0.0050^{*}$ & 0.054 \\
\hline \multirow{2}{*}{ HER2 } & +0.012 & -0.135 & +0.013 & -0.082 & +0.211 \\
\hline & 0.91 & 0.21 & 0.90 & 0.46 & 0.050 \\
\hline \multirow{2}{*}{ Ki67 } & -0.326 & -0.204 & +0.216 & +0.144 & +0.356 \\
\hline & $0.0027^{*}$ & 0.065 & 0.050 & 0.20 & $0.0010^{*}$ \\
\hline \multirow{2}{*}{ p53 } & -0.230 & -0.174 & +0.059 & -0.059 & +0.121 \\
\hline & $0.032 *$ & 0.11 & 0.58 & 0.59 & 0.26 \\
\hline
\end{tabular}

Postmenopausal women

\begin{tabular}{lrrrrr}
\hline & \multicolumn{1}{c}{ age } & \multicolumn{1}{c}{ BMI } & Tumor size & Lymph node status & Tumor grade \\
\hline \multirow{2}{*}{ ER } & $+0.127^{\mathrm{a}}$ & -0.006 & -0.064 & -0.085 & -0.134 \\
PgR & $0.073^{\mathrm{b}}$ & 0.94 & 0.37 & 0.24 & 0.059 \\
& +0.092 & +0.160 & -0.008 & -0.127 & -0.029 \\
TFF1 & 0.19 & 0.024 & 0.91 & 0.077 & 0.69 \\
& +0.088 & -0.007 & +0.076 & -0.031 & -0.035 \\
RANKL & 0.22 & 0.92 & 0.28 & 0.67 & 0.63 \\
& -0.086 & +0.021 & -0.207 & -0.031 & -0.199 \\
FOXA1 & 0.23 & 0.77 & $0.0035^{*}$ & 0.67 & 0.0051 \\
& +0.071 & -0.049 & -0.055 & -0.028 & -0.113 \\
GATA3 & 0.32 & 0.49 & 0.44 & 0.70 & 0.11 \\
& +0.079 & -0.113 & -0.112 & -0.084 & -0.188 \\
HER2 & 0.27 & 0.11 & 0.12 & 0.25 & 0.0083 \\
& -0.023 & +0.001 & -0.108 & +0.087 & -0.041 \\
Ki67 & 0.75 & 0.99 & 0.13 & 0.23 & 0.57 \\
& +0.084 & +0.045 & +0.295 & +0.127 & +0.262 \\
p53 & 0.25 & 0.54 & $<0.0001^{*}$ & 0.084 & $0.0003^{*}$ \\
& -0.020 & +0.030 & +0.024 & -0.020 & +0.270 \\
\hline Spearnan & 0.78 & 0.68 & 0.74 & 0.79 & $0.0001^{*}$ \\
\hline
\end{tabular}

a Spearman's correlation coefficient

${ }^{\mathrm{b}} P$, Spearman's rank correlation test

*Spearman's correlation coefficient $>+0.40$ or $<-0.40$ and $P<0.05$ is considered significant. 
Table 7. Univariate and multivariate analysis of factors predicting disease-free survival in pre- and postmenopausal women

\begin{tabular}{|c|c|c|c|c|c|c|}
\hline \multicolumn{7}{|l|}{ Premenopausal women } \\
\hline \multirow{2}{*}{ Factor } & \multicolumn{3}{|c|}{ Univariate } & \multicolumn{3}{|c|}{ Multivariate } \\
\hline & $\mathrm{RR}^{\mathrm{a}}$ & $95 \% \mathrm{CI}^{\mathrm{b}}$ & $P$ & $\mathrm{RR}^{\mathrm{a}}$ & $95 \% \mathrm{CI}^{\mathrm{b}}$ & $P$ \\
\hline BMI & 0.83 & 0.63 to 1.10 & & & & \\
\hline Tumor size & 1.48 & 1.20 to 1.84 & $0.0003 *$ & 1.64 & 1.01 to 2.67 & $0.044 *$ \\
\hline Lymph node status & 1.19 & 1.10 to 1.30 & $<0.0001 *$ & 1.13 & 0.98 to 1.32 & 0.10 \\
\hline Tumor grade & 1.97 & 0.56 to 6.92 & 0.29 & & & \\
\hline ER & 1.00 & 0.96 to 1.03 & 0.95 & & & \\
\hline PgR & 0.99 & 0.97 to 1.01 & 0.25 & & & \\
\hline TFF1 & 0.70 & 0.13 to 3.83 & 0.68 & & & \\
\hline RANKL & 0.53 & 0.06 to 4.60 & 0.57 & & & \\
\hline FOXA1 $(\leq 70 \%,>70 \%)$ & 0.06 & 0.01 to 0.30 & $0.0006^{*}$ & 0.73 & 0.03 to 17.40 & 0.84 \\
\hline GATA3 $(\leq 80 \%,>80 \%)$ & 0.09 & 0.01 to 0.78 & $0.029^{*}$ & 0.075 & 0.0015 to 3.66 & 0.19 \\
\hline HER2 & 0.86 & 0.30 to 2.50 & 0.79 & & & \\
\hline Ki67 $(<30 \%, \geq 30 \%)$ & 10.30 & 2.06 to 51.46 & $0.0045^{*}$ & 15.27 & 1.32 to 177.05 & $0.029 *$ \\
\hline p53 $(<10 \%, \geq 10 \%)$ & - & - & - & & & \\
\hline \multicolumn{7}{|c|}{ Postmenopausal women } \\
\hline \multirow{2}{*}{ Factor } & \multicolumn{3}{|c|}{ Univariate } & \multicolumn{3}{|c|}{ Multivariate } \\
\hline & $\mathrm{RR}^{\mathrm{a}}$ & $95 \% \mathrm{CI}^{\mathrm{b}}$ & $P$ & $\mathrm{RR}^{\mathrm{a}}$ & $95 \% \mathrm{CI}^{\mathrm{b}}$ & $P$ \\
\hline BMI & 0.96 & 0.86 to 1.07 & 0.48 & & & \\
\hline Tumor size & 1.25 & 1.00 to 1.56 & 0.051 & & & \\
\hline Lymph node status & 1.19 & 1.00 to 1.41 & $0.047^{*}$ & 1.00 & 0.84 to 1.19 & 0.98 \\
\hline Tumor grade & 2.98 & 1.32 to 6.74 & $0.0085^{*}$ & 2.17 & 0.85 to 5.56 & 0.11 \\
\hline ER & 1.01 & 0.98 to 1.03 & 0.58 & & & \\
\hline PgR & 0.99 & 0.97 to 1.00 & 0.10 & & & \\
\hline TFF1 & 2.29 & 0.88 to 5.95 & 0.09 & & & \\
\hline RANKL & 0.65 & 0.09 to 4.83 & 0.67 & & & \\
\hline FOXA1 $(\leq 70 \%,>70 \%)$ & 1.39 & 0.32 to 5.98 & 0.66 & & & \\
\hline GATA3 $(\leq 80 \%,>80 \%)$ & 0.83 & 0.34 to 2.05 & 0.69 & & & \\
\hline HER2 & 0.87 & 0.48 to 1.59 & 0.66 & & & \\
\hline Ki67 $(<15 \%, \geq 15 \%)$ & 4.46 & 1.78 to 11.18 & $0.0014 *$ & 2.22 & 0.79 to 6.28 & 0.13 \\
\hline p53 $(<10 \%, \geq 10 \%)$ & 6.01 & 2.49 to 14.51 & $0.0001 *$ & 4.03 & 1.49 to 10.92 & $0.0061^{*}$ \\
\hline
\end{tabular}




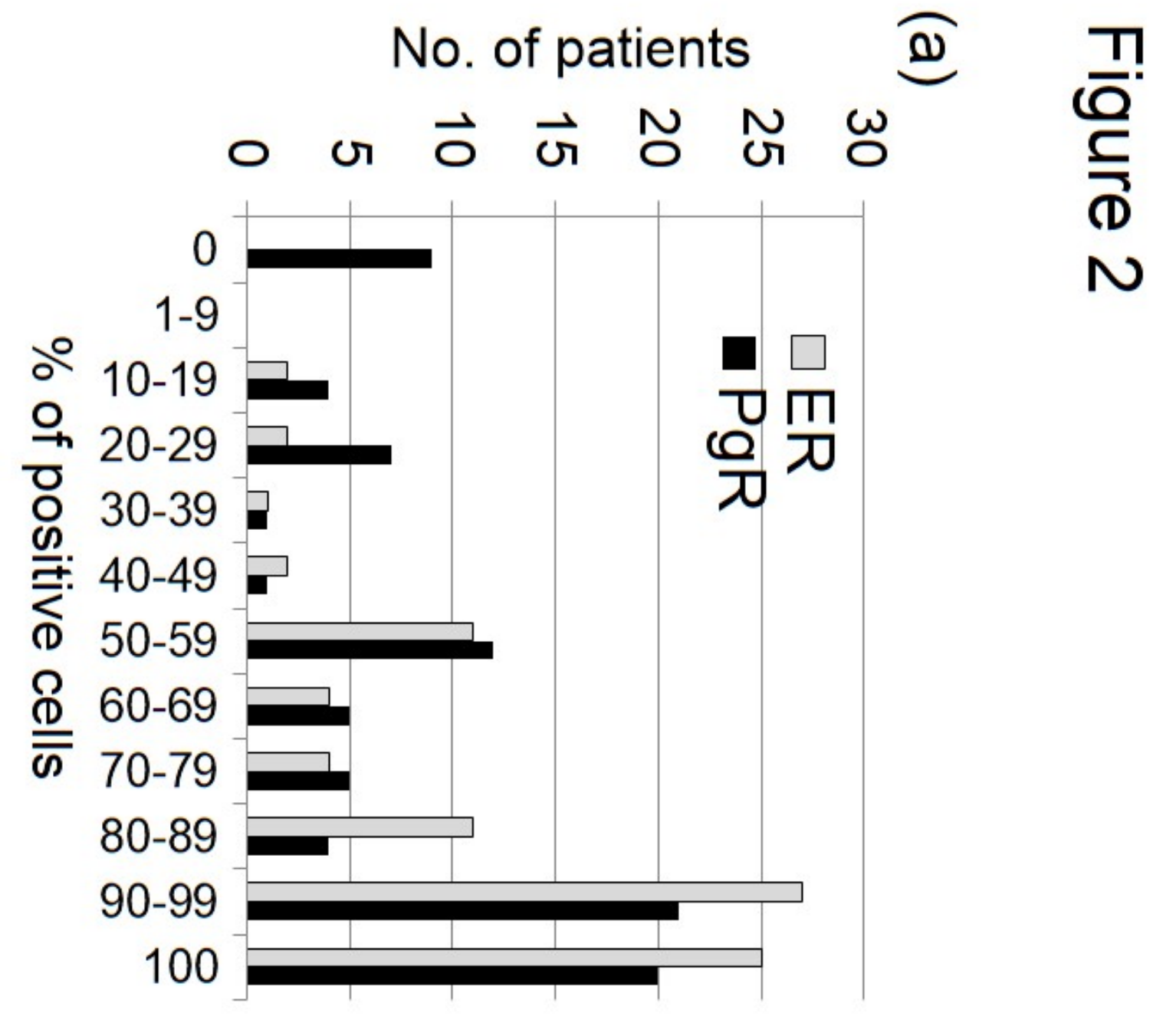

No. of patients $\widehat{\sigma}$

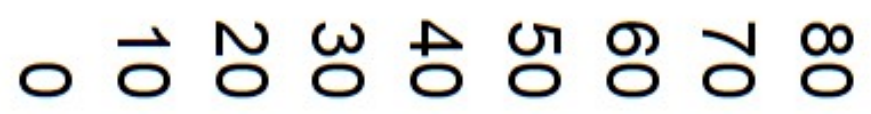

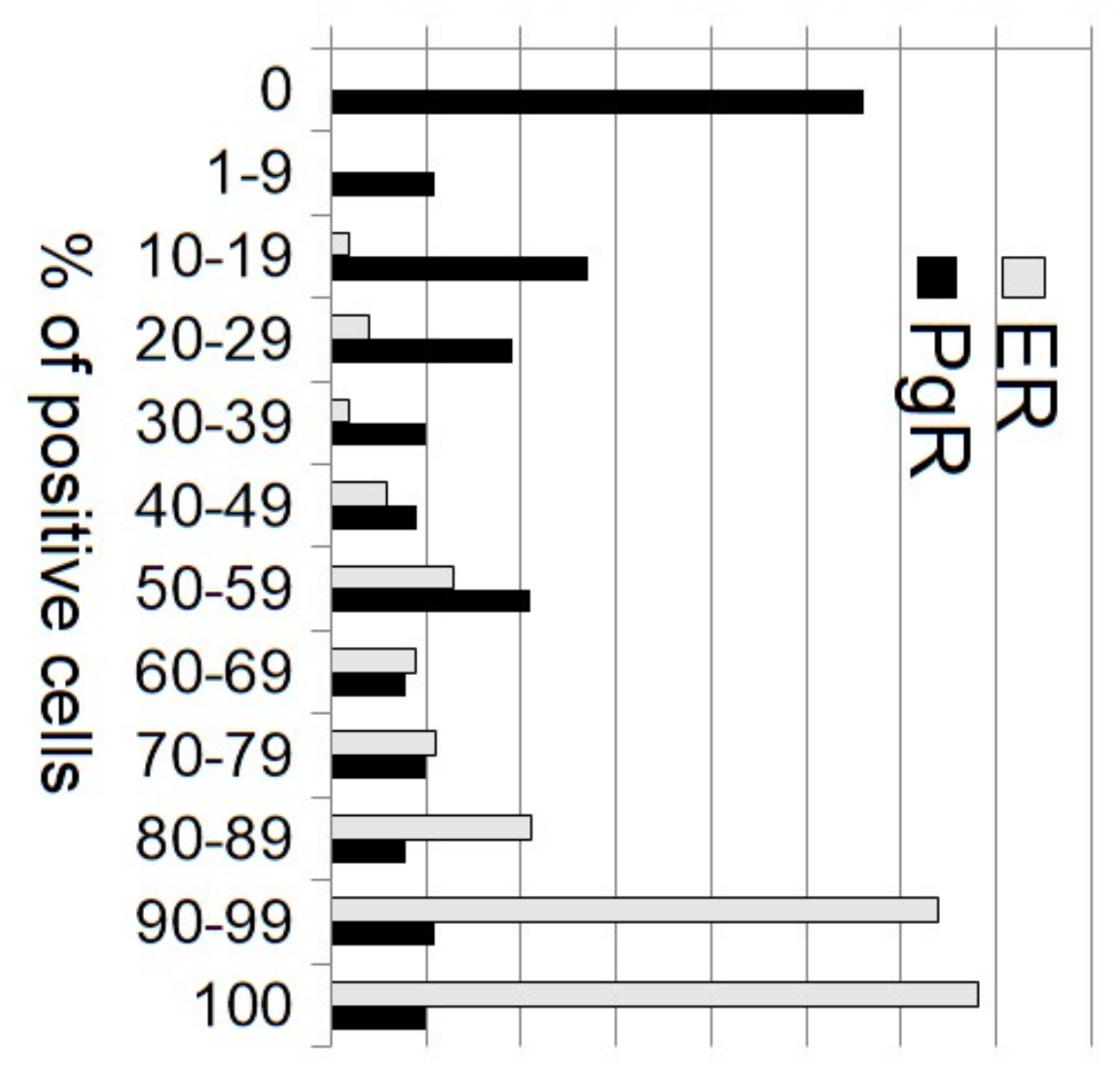




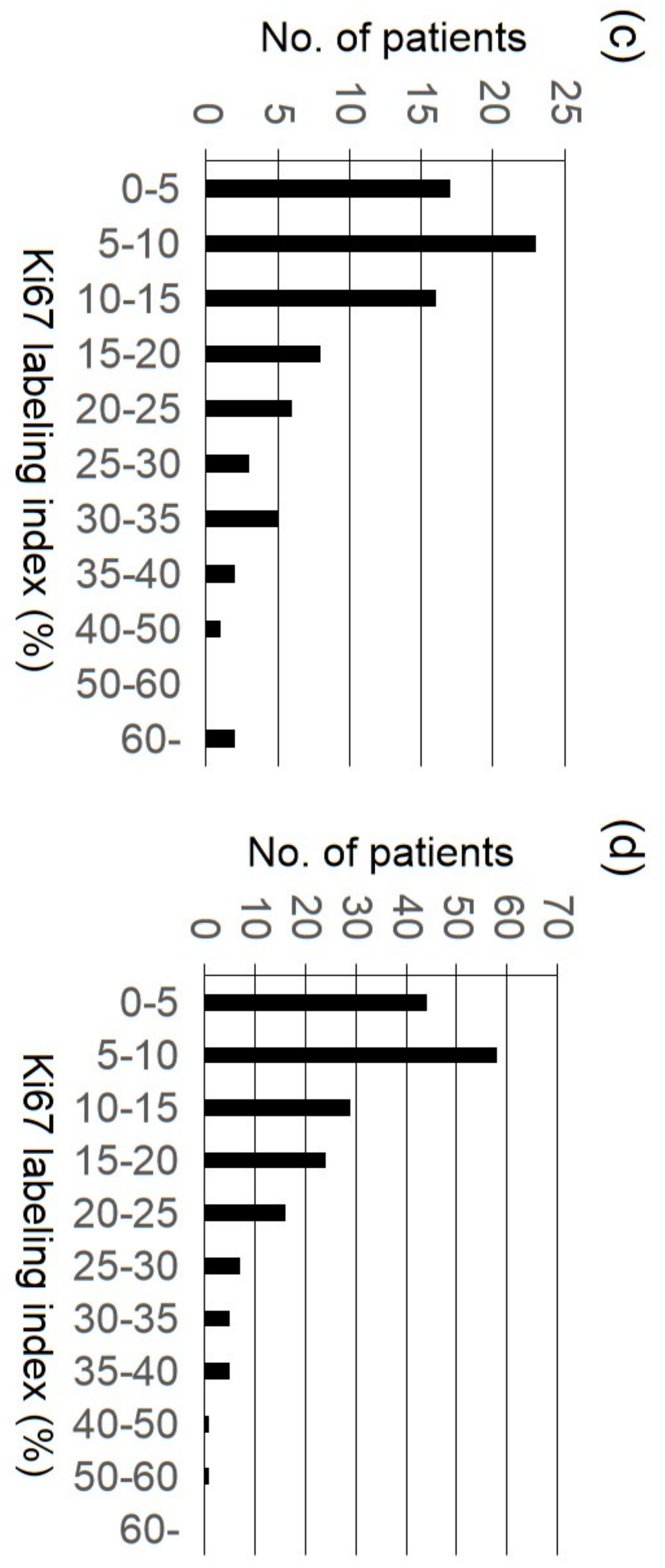



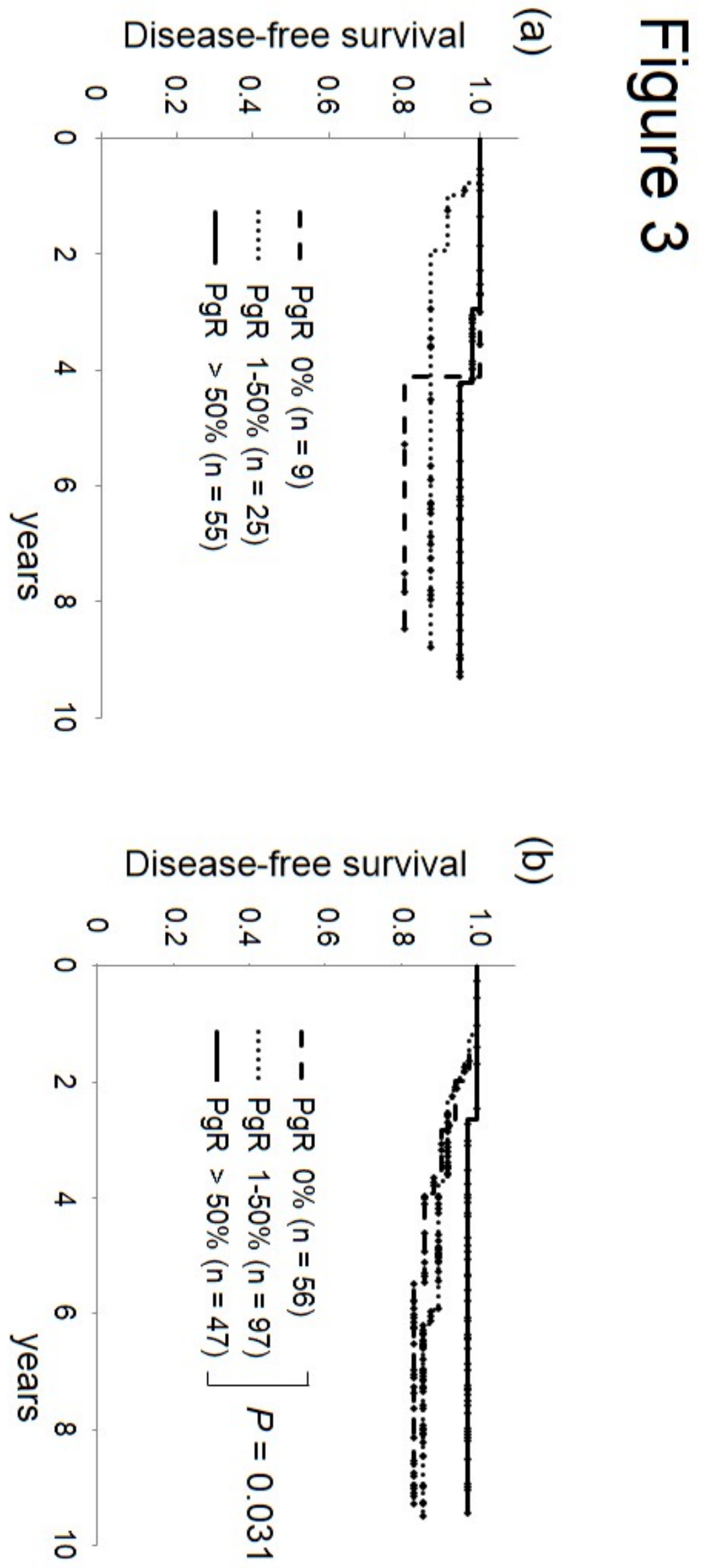

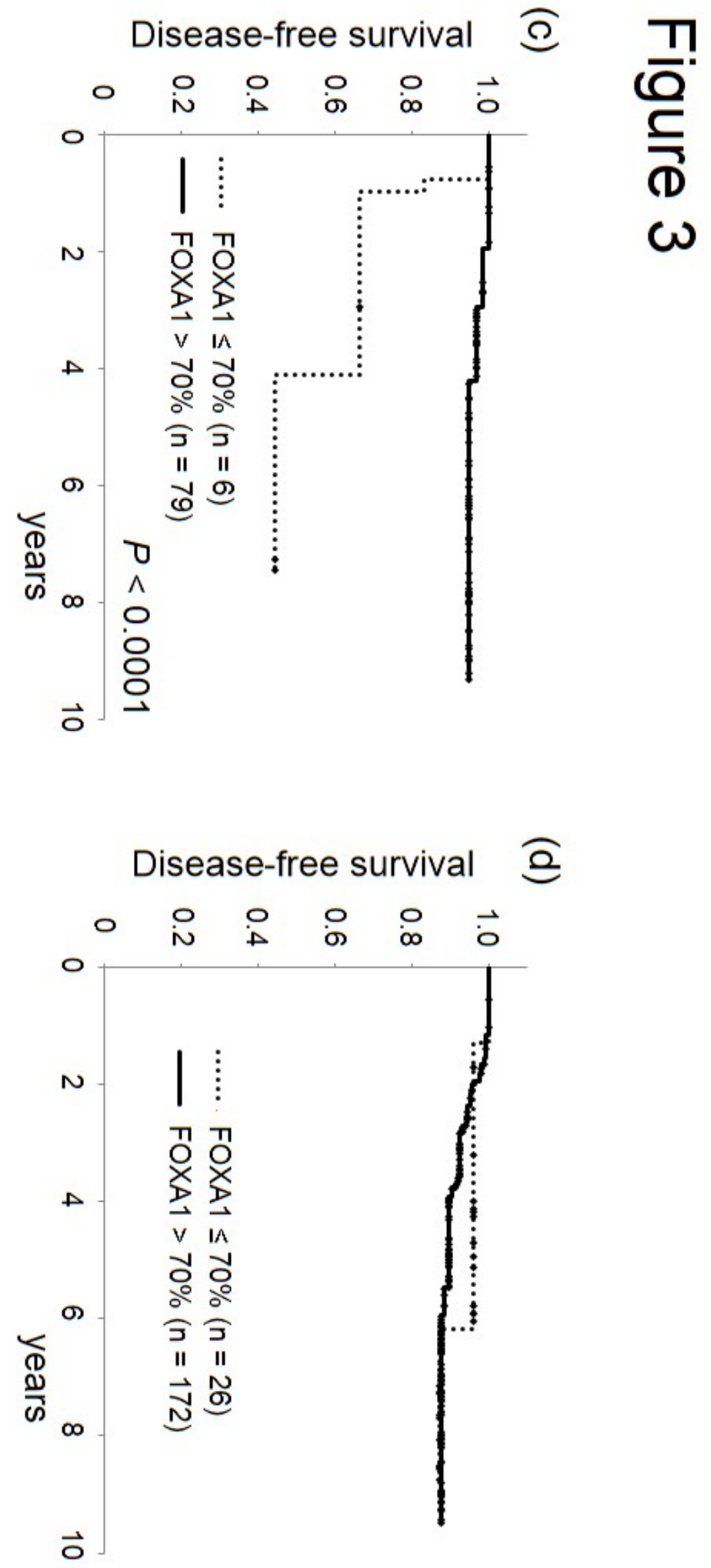

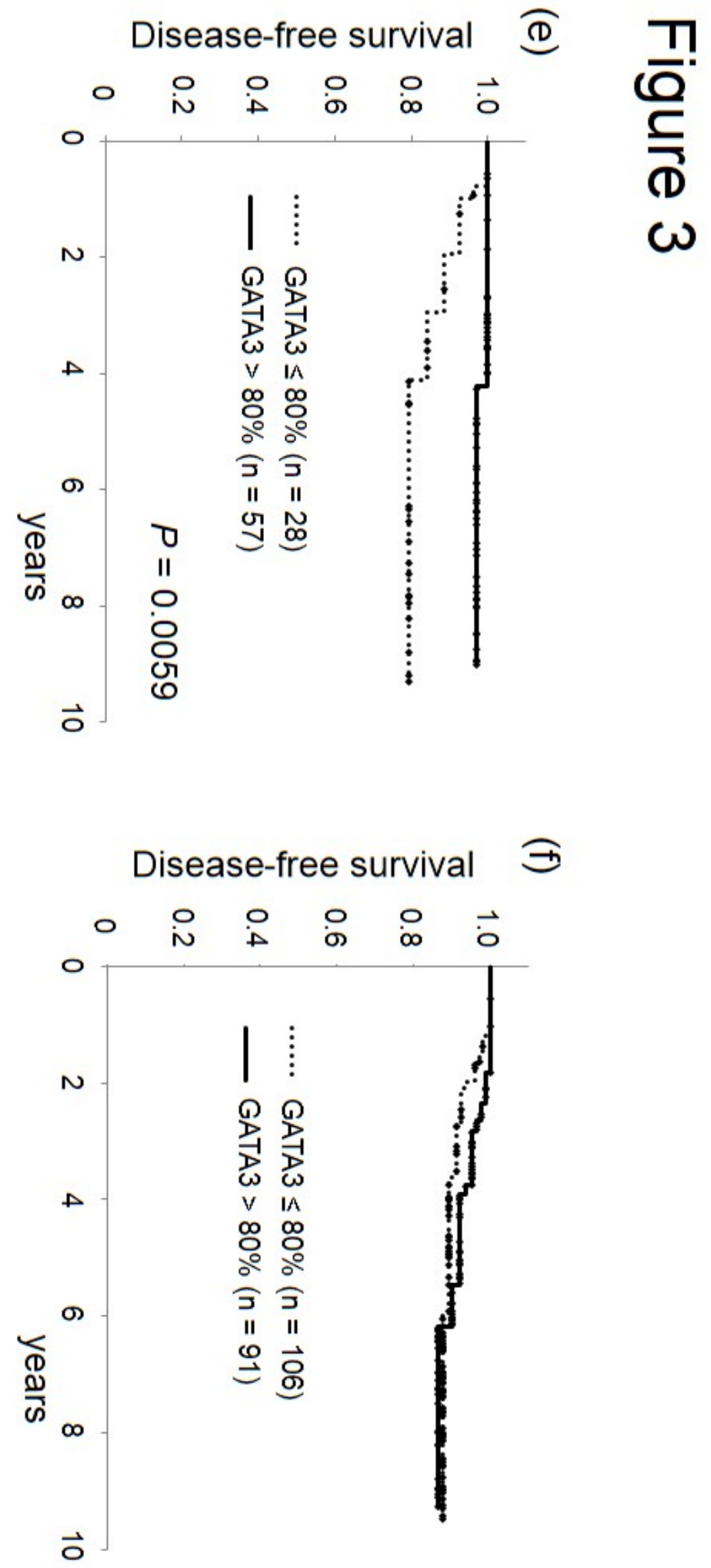

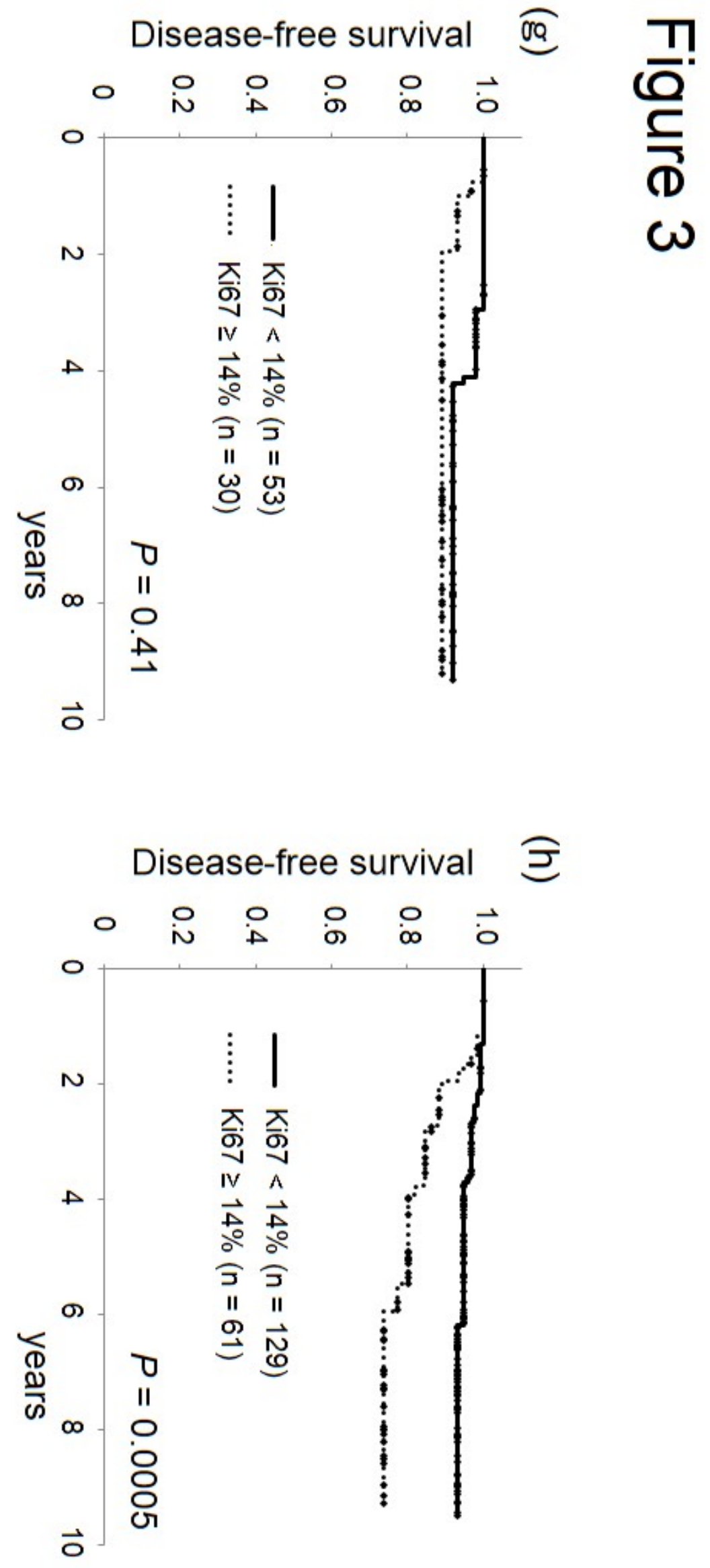

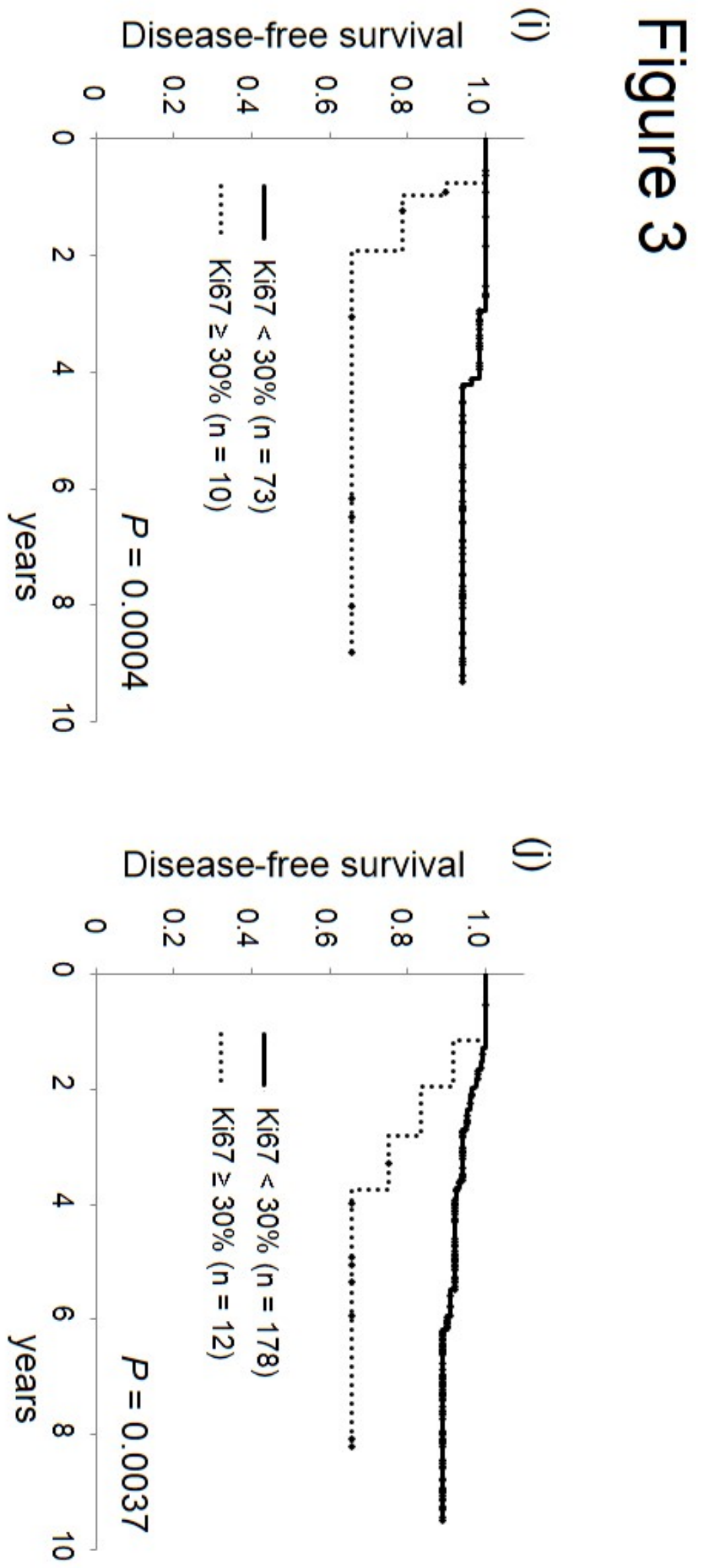

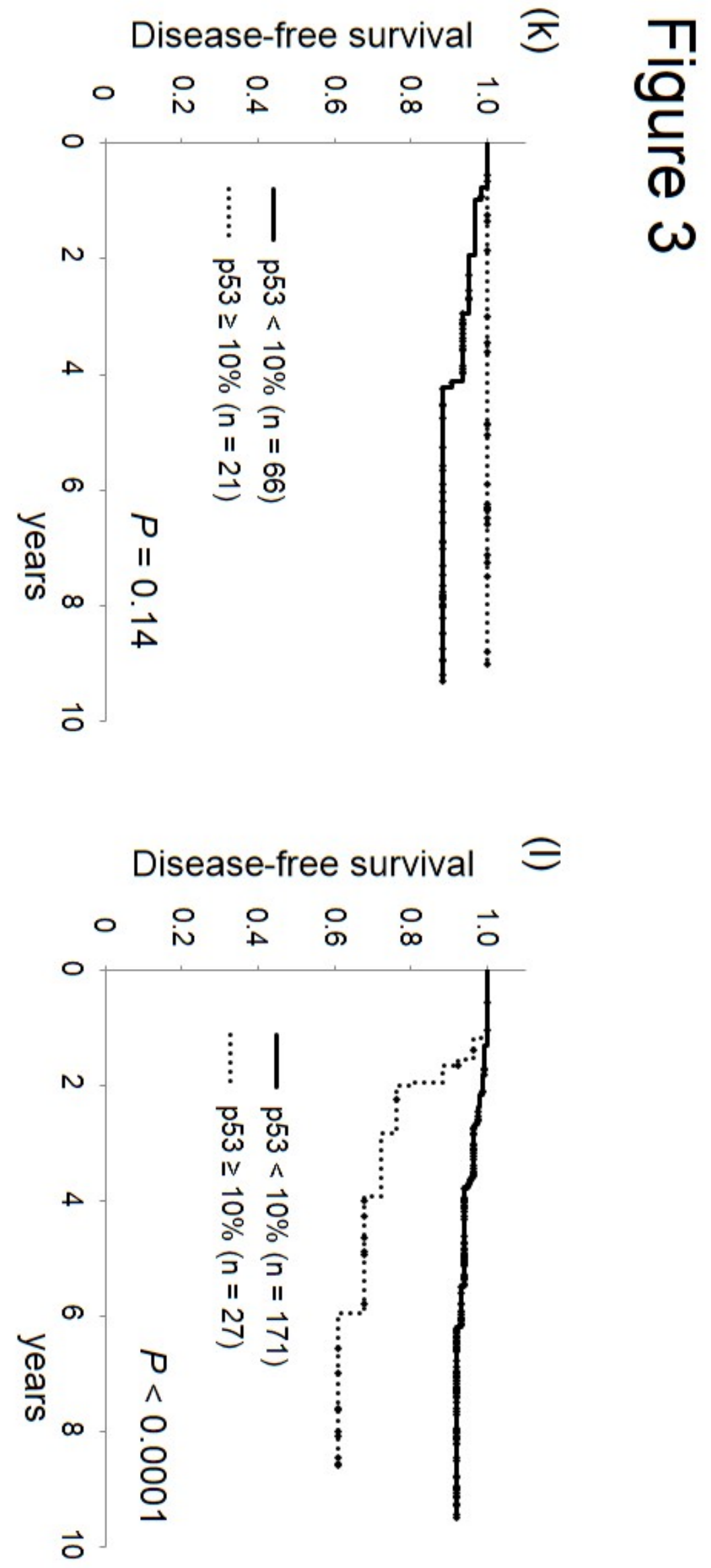